\title{
Otoneurological Abnormalities in Patients with Friedreich's Ataxia
}

\author{
Bianca Simone Zeigelboim ${ }^{1} \quad$ Juliana Cristina Mesti ${ }^{2}$ Vinicius Ribas Fonseca ${ }^{2}$ João Henrique Faryniuk ${ }^{1}$ \\ Jair Mendes Marques ${ }^{1}$ Rafaella Cardosa Cardoso ${ }^{1}$ Hélio Afonso Ghizoni Teive ${ }^{3}$
}

1 Department of Communication Disorders, Universidade Tuiuti do Paraná, Curitiba, Brazil

${ }^{2}$ Department of Otorhinolaringology, Hospital da Cruz Vermelha, Curitiba, Brazil

${ }^{3}$ Department of Internal Medicine, Hospital das Clínicas, Curitiba, Brazil

Address for correspondence Juliana Cristina Mesti, Department of Otorrinolaringologia, Hospital da Cruz Vermelha, Curitiba, 80240-020, Brazil (e-mail: jumesti@hotmail.com).

Int Arch Otorhinolaryngol 2017;21:79-85.

\begin{abstract}
Introduction Friedreich's ataxia is a neurodegenerative disease and progressive by nature. It has autosomal recessive inheritance and early onset in most cases. Nystagmus and hearing loss (in some cases) make up some of the common symptoms seen in this disorder.

Objective The objective of this study is to examine vestibular disorders in patients with Friedreich ataxia.

Methods We conducted a retrospective cross-sectional study. We evaluated 30 patients with ages ranging from six to 72 years (mean age of $38.6( \pm 14.7)$. The patients underwent the following procedures: anamnesis, ENT, and vestibular evaluations.

Results Clinically, the patients commonly had symptoms of incoordination of movement (66.7\%), gait disturbances (56.7\%), and dizziness (50\%). In vestibular testing, alterations were predominantly evident under caloric testing $(73.4 \%)$, gaze nystagmus testing (50.1\%), rotational chair testing (36.7\%), and optokinetic nystagmus testing

\section{Keywords}

- spinocerebellar ataxias

- ataxia

- spinocerebellar degenerations (33.4\%). The presence of alterations occurred under examination in $90 \%$ of subjects, with the majority occurring in those with central vestibular dysfunction (70\% of the examinations).

Conclusion The most evident neurotological symptoms were incoordination of movement, gait disturbances, and dizziness. Alterations in vestibular examinations occurred in $90 \%$ of patients, mostly in the caloric test, with a predominance of deficient central vestibular system dysfunction.
\end{abstract}

\section{Introduction}

Hereditary ataxias account for $\sim 10 \%$ of genetic diseases that affect the nervous system. Currently, more than 20 different types of autosomal recessive ataxias are mapped and classified according to their etiology. ${ }^{1}$ In this group of diseases, some are very rare and observed only in isolated populations, while others are found worldwide. ${ }^{2}$ Among them, is Friedreich's ataxia (FA), described initially by Nicholaus Friedreich in 1863, but only becoming well-known around 1882. It is a neurodegenerative disease, progressive in nature, autosomal recessive, and early onset in most cases. ${ }^{2-4}$

The first symptoms are usually observed in childhood or the early teens; however, in some cases, the diagnosis is made before the age of two years or after the age of twenty. The main features of the disease are: ataxia (impaired coordination) that initially affects the lower limbs and then the upper limbs, absence of tendon reflexes and weakness in the lower received

August 20, 2015

accepted

November 15, 2015

published online

March 31, 2016
DOI http://dx.doi.org/

10.1055/s-0036-1572529. ISSN 1809-9777.
Copyright $\odot 2017$ by Thieme-Revinter

Publicações Ltda, Rio de Janeiro, Brazil
License terms




limbs, dysarthria, loss of distal deep sensitivity, and bilateral Babinski sign. Nerve conduction studies show axonal sensory neuropathy. ${ }^{5-7}$ Other main problems associated to the condition are: nystagmus, optic atrophy, hearing loss (which may be present), atrophy in hands and distal lower limbs, scoliosis, pes cavus, and claw toes. ${ }^{2-7}$ Diabetes is present in $10 \%$ of cases and cardiomyopathy occurs in approximately two-thirds of patients, making the latter the leading cause of death. ${ }^{7-9}$ There are significant variations in the average duration of the disease, from the onset of symptoms until death, which tends to occur around the fourth decade of life. , $^{5,8,10}$

The diagnosis of FA is performed by means of clinical and genetic data.

Spinocerebellar ataxias (SCAs) are part of a list of diseases that, by their manifestations and impairment areas, can lead to vestibular disorders. The vestibular evaluation is an important tool in confirmation of vestibular disorders and their relationship with the central nervous system. The tests that comprise the vestibular examination make it possible to assess balance and its relationship to the function of the posterior labyrinth, vestibular branches of cranial nerve VIII, vestibular nuclei at the floor of the fourth ventricle, vestibular pathways and, above all, vestibular-oculomotor, vestibulocerebellar, vestibulospinal, and vestibular and neck proprioceptive relationships. ${ }^{11}$

The aim of this study was to investigate the vestibular disorders in patients with Friedreich's ataxia.

\section{Materials and Methods}

This study was approved by the Institutional Ethics Committee under registration number $058 / 2008$ and authorized by the patients' signing of a consent form.

A retrospective cross-sectional study was conducted. We evaluated 30 patients ( 10 female and 20 male) directed by the Department of Internal Medicine at the Hospital de Clinicas for evaluation by the Otoneurology Department of an educational institution in the same city, with a diagnosis of Friedreich's-type recessive SCA (FA). The diagnosis of ataxia was performed by means of genetic testing using Polymerase Chain Reaction (PCR) (-Table 1). ${ }^{12-14}$ To measure the severity of cerebellar ataxia in an easier and more practical manner, Schmitz-Hübsch et al ${ }^{15}$ proposed a scale for the assessment and rating of ataxia (SARA) which was translated and validated in Brazilian Portuguese by Braga-Neto el al. ${ }^{16}$ The SARA has eight questions that yield a total score of 0 (no ataxia) to 40 (most severe ataxia); 1 : gait (score 0 to 8 ), 2: stance (score 0 to 6 ), 3: sitting (score 0 to 4 ), 4 : speech disturbance (score 0 to 6 ), 5 : finger-chase test (score 0 to 4 ), 6: nose-finger test (score 0 to 4), 7: fast alternating hand movements (score 0 to 4 ), 8: heel-shin coordination test (score 0 to 4 ). Kinetic limb functions (items 5 to 8 ) are rated independently for both sides, and the arithmetic mean of both sides is included in the SARA total score. ${ }^{15}$ This scale has proven to be a valid and trustworthy measurement in SCA patients.

Excluded from the study were patients that presented with otological alterations or other abnormalities that prevented the completion of testing.

The following procedures were performed:
Table 1 Aspects of Friedreich's ataxia

\begin{tabular}{|c|c|c|c|c|}
\hline CASE & $\begin{array}{l}\text { AGE } \\
\text { (years) }\end{array}$ & SEX & $\begin{array}{l}\text { DISEASE DURATION } \\
\text { (years) }\end{array}$ & SARA \\
\hline 1 & 43 & $\mathrm{M}$ & 25 & 20 \\
\hline 2 & 41 & $\mathrm{M}$ & 7 & 3,5 \\
\hline 3 & 30 & $\mathrm{~F}$ & 18 & 8 \\
\hline 4 & 24 & $\mathrm{M}$ & 8 & 4 \\
\hline 5 & 29 & $M$ & 13 & 14 \\
\hline 6 & 17 & $M$ & 3 & 13 \\
\hline 7 & 63 & $\mathrm{~F}$ & 38 & 7 \\
\hline 8 & 6 & $\mathrm{~F}$ & 6 & 19 \\
\hline 9 & 37 & $\mathrm{~F}$ & 19 & 16 \\
\hline 10 & 41 & $\mathrm{~F}$ & 20 & 29,5 \\
\hline 11 & 27 & $\mathrm{~F}$ & 12 & 14 \\
\hline 12 & 25 & $\mathrm{~F}$ & 12 & 12 \\
\hline 13 & 55 & $\mathrm{~F}$ & 30 & 7 \\
\hline 14 & 44 & $\mathrm{M}$ & 10 & 3,5 \\
\hline 15 & 55 & $M$ & 12 & 14 \\
\hline 16 & 37 & $M$ & 17 & 19 \\
\hline 17 & 51 & $\mathrm{M}$ & 30 & 29 \\
\hline 18 & 27 & $\mathrm{M}$ & 10 & 16 \\
\hline 19 & 46 & $M$ & 18 & 10 \\
\hline 20 & 72 & $\mathrm{M}$ & 42 & 28 \\
\hline 21 & 52 & $\mathrm{~F}$ & 18 & 3 \\
\hline 22 & 30 & $M$ & 4 & 4,5 \\
\hline 23 & 37 & $M$ & 19 & 18 \\
\hline 24 & 44 & $\mathrm{M}$ & 18 & 9,5 \\
\hline 25 & 22 & $\mathrm{M}$ & 14 & 5 \\
\hline 26 & 42 & $\mathrm{~F}$ & 31 & 25 \\
\hline 27 & 63 & $\mathrm{M}$ & 18 & 19 \\
\hline 28 & 42 & $M$ & 21 & 8 \\
\hline 29 & 28 & $M$ & 21 & 8 \\
\hline 30 & 30 & $M$ & 17 & 13 \\
\hline
\end{tabular}

Abbreviations: F, female; M, male; SARA, scale for the assessment and rating of ataxia.

\section{Anamnesis}

A questionnaire was given focusing on otoneurological signs and symptoms (-Fig. 1).

\section{Ear, Nose, and Throat (ENT) Evaluation}

An ENT evaluation was performed to rule out any alterations that could affect the test.

\section{Vestibular Assessment}

Patients underwent the following tests that make up the vestibular examination. Initially, we checked vertigo and spontaneous and semi-spontaneous positional nystagmus.

Then, to analyze vectoelectronystagmography (VENG), we used a three-channel thermosensitive Berger VN316 model 


\section{ANAMNESIS}

I. Identification

Date: $\quad$ I

Name:

Age:

Country of Birth:

Occupation:

\section{Professional Activity}

Previous jobs:

Total time working: in noisy place exposed to chemical agents

Is currently ( ) or has been ( ) exposed to chemical agents:

heawy metals (lead, mercury):

asphyxiant (e.g. $\left.\mathrm{CO}_{2}\right)$ :

\section{History of Morbidity}

Smokes ( jor has been a smoker ( )?

How many packs per day? How many cigarettes per day?

Consumes alcohol regularly? ( ) No ( ) Yes How much per day-

Consumes caffeine? ( No ( Yes How much per day

Dietary errors:

Takes medication? ( ) No ( ) Yes Which ones:

Had surgery? ( ) No () Yes what:

Identify subject's health problems:

\begin{tabular}{l|l|l|l}
\hline Signs and Symptoms & Yes & No & Medication taken \\
\hline Change in blood flow & & & \\
\hline Hypertension & & & \\
\hline Sensitivity change & & & \\
\hline Incoordination of mowement & & & \\
\hline Sensation of movement of objects & & & \\
\hline Diabetes & & & \\
\hline Thyroid dysfunction & & & \\
\hline Craniogncephalic trauma & & & \\
\hline Heart disease & & & \\
\hline Kidney damage & & & \\
\hline Rheumatologic disorders & & & \\
\hline Degenerative Diseases & & & \\
\hline ThJ disorder & & & \\
\hline Dysarthria & & & \\
\hline Alteration in smel|f taste & & & \\
\hline Pain / Difficulty in moving neck & & & \\
\hline Tingling in extremities & & & \\
\hline Dysphonia & & & \\
\hline Dysphagia & & & \\
\hline Double i blured wision & & & \\
\hline Fatigue & & & \\
\hline Anxiety i fear / depression & & & \\
\hline Headache / migraine & & & \\
\hline
\end{tabular}

\section{Hearing Loss}

Onset:
Intensity: Ocale: ( ) right ear ( ) left ear ( ) both
Purging in ear: ( ) Yes ( ) No
Appears or worsens:
Triggering factors:
Aggravating factors:
Factors for improvement:
Concomitant symptoms:

Fig. 1 Anamnesis by Otoneurology Department. 


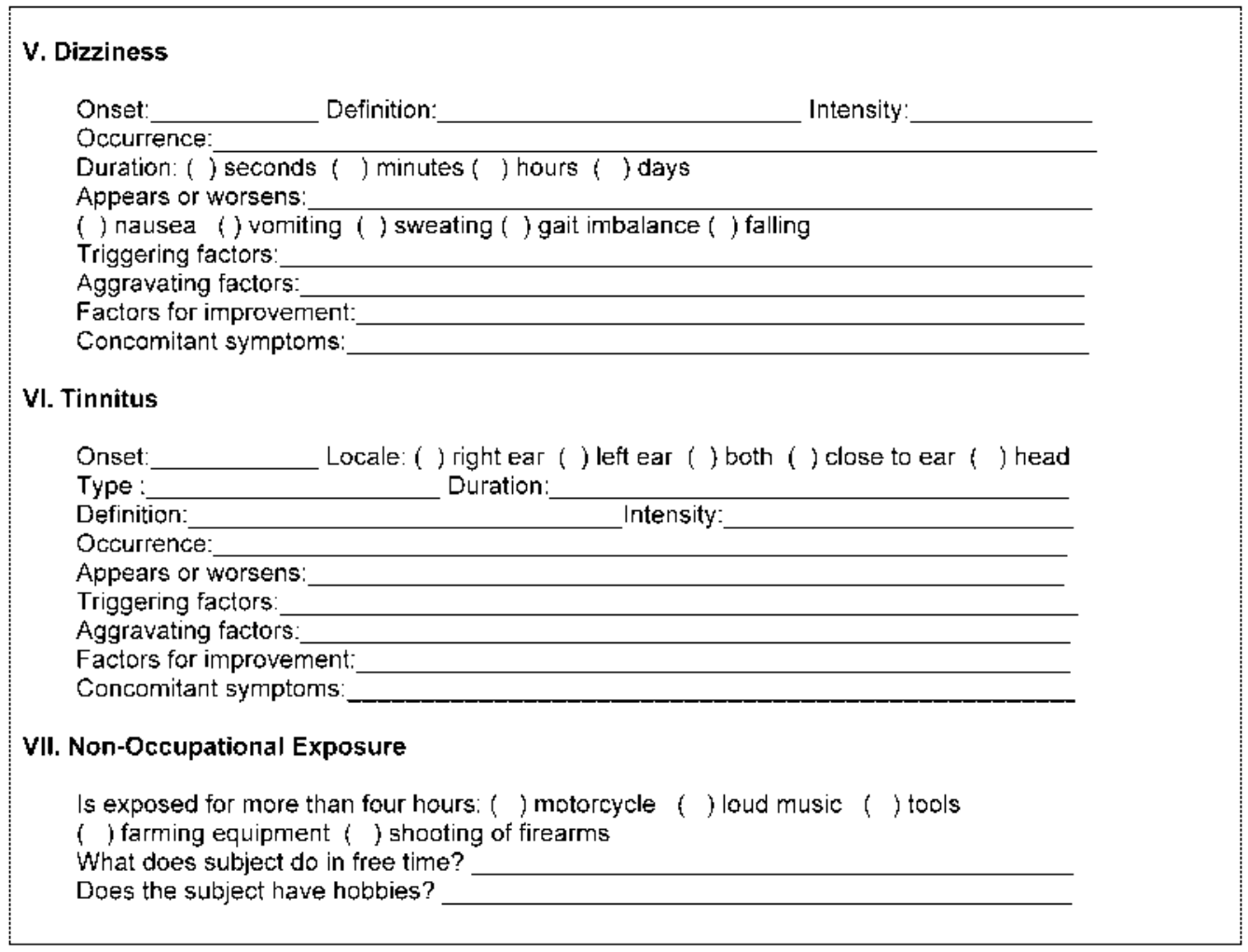

Fig. 1 (Continued)

device along with a Ferrante swivel chair, a Neurograff Eletromedicina Ltda. model EV VEC visual stimulator, and a Neurograff ear calorimeter model NGR 05 (Vn 316 model, São Paulo, Brazil) for measuring air temperature.

Next, we conducted the eye and labyrinth VENG tests, according to criteria proposed by Mangabeira-Albernaz, Ganança, and Pontes. ${ }^{17}$

*Eye movement calibration - We verified spontaneous and semi-spontaneous nystagmus using pendular tracking, checking for pre- and post-rotatory plus pre- and post-caloric optokinetic nystagmus. We recorded the caloric stimulation time in each ear using air at $42^{\circ} \mathrm{C}$ and $18^{\circ} \mathrm{C}$ lasted 80 seconds for each temperature and responses with eyes closed and then with eyes open to observe the inhibitory effect of eye fixation (IEEF). The criteria used in the air caloric test were: absolute value between 2 and 24 degrees/ sec ( $<2$ degrees/ sec (hyporeflexia), $>24$ degrees/ sec (hyperreflexia); relative values of labyrinth preponderance (LP) $<41 \%$ and nystagmus directional preponderance (NDP) $<36 \%{ }^{18}$

\section{Statistical Analysis}

We used a difference of proportions test to compare the results of the vestibular examination (analyzing normal and abnormal results) and to correlate FA with the most altered results from the vestibular examination (caloric, semi-spontaneous nystagmus, rotatory, and optokinetic tests) and below, with the most frequent otoneurological symptoms (incoordination of movement, imbalance of gait, and dizziness). Finally, we applied the
Fisher test correlating the results of the vestibular examination with otoneurological symptoms of major occurrence. In all cases, we considered $p<0.05$ to be statistically significant.

\section{Results}

The subjects' ages ranged from six to 72 years, with a mean age 38.6 years and a standard deviation of 14.7 years. The average duration of the disease was 17.7 years and the standard deviation was 9.4 years.

The most frequent complaints in the anamneses were incoordination of movement $(66.7 \%)$, gait imbalance $(56.7 \%)$, dizziness (50\%), and dysarthria (46.7\%), as shown in - Table 2.

In assessing the vestibular function, the caloric test, spontaneous and semi-spontaneous, rotatory, optokinetic, and pendulum tracking showed alterations in FA, as shown in - Table 3.

Among the tests with alterations in FA, the highest prevalence occurred in: the caloric test $(73.4 \%)$ with a predominance of hyporeflexia (53.3\%); then, the test for semi-spontaneous nystagmus (50.1\%), with a predominance of the multiple type (40\%); next, the rotatory test (36.7\%), which denotes a lack of response from lateral, anterior, and posterior semicircular canals; and optokinetic (33.4\%), which shows a change in pursuit movements, as observed in -Table 3.

The use of the difference of proportions test proves that there was significance in the correlation between FA with labyrinthine and eye tests that showed more alterations than the others, the caloric test with rotatory $(p=0.0065)$ and caloric with optokinetic ( $p=0.0032)$. 
Table 2 Distribution in frequency of symptoms in 30 Friedreich's ataxia patients

\begin{tabular}{|l|l|l|}
\hline SYMPTOMS & $\begin{array}{l}\text { NUMBER OF } \\
\text { PATIENTS }\end{array}$ & $\begin{array}{l}\text { FREQUENCY } \\
\text { (\%) }\end{array}$ \\
\hline Incoordination of movement & 20 & 66.7 \\
\hline Gait imbalance & 17 & 56.7 \\
\hline Dizziness & 15 & 50.0 \\
\hline Dysarthria & 14 & 46.7 \\
\hline Headache & 10 & 33.4 \\
\hline Dysphagia & 9 & 30.0 \\
\hline Diplopia & 9 & 30.0 \\
\hline Falling & 8 & 26.7 \\
\hline Tremors & 8 & 26.7 \\
\hline Depression & 8 & 26.7 \\
\hline Fatigue & 7 & 23.4 \\
\hline Anxiety & 7 & 23.4 \\
\hline Difficulty moving the neck & 6 & 20.0 \\
\hline $\begin{array}{l}\text { Pain radiating to } \\
\text { the shoulder and arm }\end{array}$ & 5 & 16.7 \\
\hline Tingling in extremities & 4 & 13.4 \\
\hline Insomnia & 3 & 10.0 \\
\hline Neck cracking & 3 & 10.0 \\
\hline Hearing loss & 3 & 10.0 \\
\hline Olfactory change & 2 & 6.7 \\
\hline Gustative change & 2 & 3.4 \\
\hline Dysphonia & 1 & \\
\hline & & \\
\hline
\end{tabular}

Table 3 Distribution in frequency of alterations in vestibular exam in 30 patients with Friedreich's ataxia

\begin{tabular}{|l|l|l|}
\hline \multirow{2}{*}{ ALTERED EXAMS } & \multicolumn{2}{|l|}{$\begin{array}{l}\text { FRIEDREICH'S } \\
\text { ATAXIA }\end{array}$} \\
\cline { 2 - 3 } & $\mathrm{N}$ & $\%$ \\
\hline Bilateral labyrinthine hyporeflexia & 16 & 53.3 \\
\hline $\begin{array}{l}\text { Multiple semi-spontaneous } \\
\text { nystagmus }\end{array}$ & 12 & 40.0 \\
\hline Absent rotary nystagmus & 11 & 36.7 \\
\hline $\begin{array}{l}\text { Asymmetrical optokinetic } \\
\text { nystagmus }\end{array}$ & 10 & 33.4 \\
\hline Spontaneous nystagmus & 6 & 20.0 \\
\hline Pendulum tracking alterations & 5 & 16.7 \\
\hline Bilateral labyrinthine hyperreflexia & 5 & 16.7 \\
\hline $\begin{array}{l}\text { Bidirectional semi-spontaneous } \\
\text { nystagmus }\end{array}$ & 2 & 6.7 \\
\hline $\begin{array}{l}\text { Unidirectional semi-spontaneous } \\
\text { nystagmus }\end{array}$ & 1 & 3.4 \\
\hline Unilateral labyrinthine hyperreflexia & 1 & 3.4 \\
\hline
\end{tabular}

Abbreviations: \%, frequency; $\mathrm{N}$, number of patients.
Regarding the outcome of the vestibular examination, there was a higher incidence of central vestibular dysfunction (70\%), as shown in - Table 4.

The implementation of the difference of proportions test proves that there was a significant difference between the proportions of normal tests and those that showed alterations $(p=0.0000)$.

The correlation between FA and the three most frequent otoneurological symptoms, can be seen in - Table $\mathbf{5}$.

The implementation of the difference of proportions test proves that there was no significant difference in the correlation between FA symptoms of incoordination of movement and gait imbalance $(p=0.42890)$, gait imbalance and dizziness ( $p=0.6049$ ), and dizziness and incoordination of movement $(p=0.1867)$.

The result of the vestibular examination and the most frequent otoneurological symptoms is shown in - Table 6 .

In the application of Fisher's test, there was no significant difference in the correlation between the results of the entrance examination with the symptoms of incoordination of movement and gait imbalance $(p=0.4595)$, incoordination of movement and dizziness $(p=0.4286)$, and gait imbalance and dizziness ( $p=0.7258)$.

\section{Discussion}

The most commonly reported symptoms by patients were also observed in several other studies. ${ }^{19-22}$ Because of the illness' multidisciplinary clinical characteristics, various events may occur with disease progression.

Table 4 Frequency of results from vestibular exam in 30 patients with Friedreich's ataxia

\begin{tabular}{|l|l|l|}
\hline \multirow{2}{*}{ VESTIBULAR EXAM RESULT } & \multicolumn{2}{l|}{$\begin{array}{l}\text { FRIEDREICH'S } \\
\text { ATAXIA }\end{array}$} \\
\cline { 2 - 3 } & $\mathrm{N}$ & $\%$ \\
\hline Central vestibular disorder & 21 & 70.0 \\
\hline Peripheral vestibular disorder & 6 & 20.0 \\
\hline Normal vestibular exam & 3 & 10.0 \\
\hline Total & 30 & 100.0 \\
\hline
\end{tabular}

Abbreviations: $\mathrm{N}$, number of patients; \%, frequency.

Table 5 Correlation among most common otoneurological symptoms in 30 patients with Friedreich's ataxia

\begin{tabular}{|l|l|l|}
\hline \multirow{2}{*}{ SYMPTOMOLOGY } & \multicolumn{2}{|l|}{$\begin{array}{l}\text { FRIEDREICH'S } \\
\text { ATAXIA }\end{array}$} \\
\cline { 2 - 3 } & $\mathrm{N}$ & $\%$ \\
\hline Incoordination of movement & 20 & 66.7 \\
\hline Gait imbalance & 17 & 56.7 \\
\hline Dizziness & 15 & 50.0 \\
\hline
\end{tabular}

Abbreviations: N, number of patients; \%, frequency. 
Table 6 Correlation between vestibular exam and most common otoneurological symptoms in 30 patients with Friedreich's ataxia

\begin{tabular}{|l|l|l|l|l|l|l|}
\hline \multirow{2}{*}{ VESTIBULAR EXAM RESULT } & \multicolumn{2}{l|l|}{$\begin{array}{l}\text { INCOORDINATION } \\
\text { OF MOVEMENT }\end{array}$} & \multicolumn{2}{l|}{ GAIT IMBALANCE } & \multicolumn{2}{l|}{ DIZZINESS } \\
\cline { 2 - 8 } & $\mathrm{N}$ & $\%$ & $\mathrm{~N}$ & $\%$ & $\mathrm{~N}$ & $\%$ \\
\hline Normal vestibular exam & - & 0.0 & 1 & 3.4 & 1 & 3.4 \\
\hline Altered vestibular exam & 20 & 66.7 & 16 & 53.3 & 14 & 46.6 \\
\hline Total & 20 & 66.7 & 17 & 56.7 & 15 & 50.0 \\
\hline
\end{tabular}

Abbreviations: $\mathrm{N}$, number of patients; \%, frequency.

Nacamagoe, Iwamoto, and Yoshida ${ }^{23}$ reported that the combination of vestibular dysfunction in the presence of cerebellar atrophy can contribute significantly to the appearance of gait instability, which is part of the initial symptomatology of SCAs.

In this study, the videonystagmography (VNG) examination showed a higher prevalence of vestibular dysfunction (53.3\%), as well as altered multiple-type semi-spontaneous nystagmus (40\%), rotatory (36.7\%), and optokinetic (33.4\%) tests. Cerebellar vermis lesions cause ataxia of the upper limbs, head wobbling, dysmetria, and trembling eye movements, which is the body part that manifests electrical activity along the length of the eye muscles and neck. ${ }^{24}$ The most common alterations in other studies ${ }^{11,22,24}$ were the presence of positional nystagmus, irregular eye movement calibration, spontaneous rebound nystagmus, bi- and multi-directional semi-spontaneous nystagmus, abolition of optokinetic nystagmus, pendular tracking type IV nystagmus, hyporeflexia, absence of inhibitory effect of eye fixation, and Aubry signs in the Barany test. Among the damaged neuronal structures, the occurrence of vestibular dysfunction is known, but little is known about when and why it occurs. Takegoshi and Murofushi ${ }^{25}$ report that spinocerebellar ataxia is one of the clinical entities in vestibular disorders.

Prim-Espada et $\mathrm{al}^{26}$ performed an eletrooculographic examination (EOG) on 51 patients diagnosed with genetic FA and observed alterations in saccadic movements for positional, spontaneous, and optokinetic nystagmus. The authors refer to suppression of the vestibular-ocular reflex (VOR) in all patients. Fahey et al ${ }^{27}$ evaluated 20 patients with FA and observed that, despite presenting normal saccadic speed, extended latency was present. In addition, vestibular disorders were found with a marked reduction in the increase of the VOR. For Hocking, Fielding, and Corben, ${ }^{28}$ altered saccadic latency can be useful as a marker of severity and progression in FA. Noval et $\mathrm{al}^{29}$ performed eye examinations on 23 patients with FA and observed that visual acuity may decrease with disease progression, based on a small proportion of the patients without citing the percentage.

Zeigelboim et $\mathrm{al}^{11}$ report that the loss of hair cells of the ampullary crests, as well as the decline in the number of nerve cells in the vestibular ganglion (Scarpa), degeneration of the otoliths, reduced labyrinthine blood flow, progressive depression of neural stability, and reduction in the compensation capacity of the vestibular-ocular and vestibulospinal reflexes all contribute to the reduction of speed in the eye tracking motion, as well as rotatory and caloric hyporeactivity in the vestibular system, both peripheral and central, present in SCAs.

In this study, the result of the vestibular exam had a significant predominance of central vestibular dysfunction in $70 \%$ of patients. Ito et $\mathrm{al}^{22}$ showed involvement of the central vestibular system and stressed the importance of vestibular evaluation in diseases affecting the posterior fossa. Prim-Espada et $\mathrm{a}^{26}$ observed central alterations in the EOG exam in $72.5 \%$ of patients and Monday and Lemieux, ${ }^{30}$ in $100 \%$ of cases via EOG exams. Fahey et $\mathrm{al}^{27}$ and Kirkham et a ${ }^{31}$ stressed that the range of alterations for eye movements suggest alterations in the brain stem, as well as the cortical and vestibular pathways.

In this study, we did not observe significance in the intercorrelation between the most evident symptoms (lack of coordination of movement, gait imbalance, and dizziness) for FA. We found no data that would challenge our findings.

It was evident that alterations in VNG are related to the severity of SCAs or the clinical stage of the disease.

The study emphasizes the importance of the vestibular evaluation for the topographic diagnosis of neurodegenerative diseases since, in most cases, the otoneurological symptoms present early and such information may aid in the choice of procedures to be performed in clinical and therapeutic monitoring.

\section{Conclusion}

The most prevalent otoneurological symptoms were incoordination of movement, gait imbalance, and dizziness.

Alterations in the vestibular examination occurred in $90 \%$ of patients, located mainly in the caloric test, with a predominance of deficient central vestibular system dysfunction.

\section{References}

1 Fogel BL, Perlman S. Clinical features and molecular genetics of autosomal recessive cerebellar ataxias. Lancet Neurol 2007;6(3): 245-257

2 Embiruçu EK, Martyn ML, Schlesinger D, Kok F. Autosomal recessive ataxias: 20 types, and counting. Arq Neuropsiquiatr 2009; 67(4):1143-1156

3 Ell J, Prasher D, Rudge P. Neuro-otological abnormalities in Friedreich's ataxia. J Neurol Neurosurg Psychiatry 1984;47(1):26-32

4 Rinaldi C, Tucci T, Maione S, Giunta A, De Michele G, Filla A. Lowdose idebenone treatment in Friedreich's ataxia with and without cardiac hypertrophy. J Neurol 2009;256(9):1434-1437 
5 Albano LMJ, Zatz M, Kim CA, et al. Friedreich's ataxia: clinical and molecular study of 25 Brazilian cases. Rev Hosp Clin Fac Med Sao Paulo 2001;56(5):143-148

6 Alper G, Narayanan V. Friedreich's ataxia. Pediatr Neurol 2003; 28(5):335-341

7 Pandolfo M. Friedreich ataxia. Arch Neurol 2008;65(10): 1296-1303

8 Fortuna F, Barboni P, Liguori R, et al. Visual system involvement in patients with Friedreich's ataxia. Brain 2009;132(Pt 1):116-123

9 Melo M, Fagulha A, Barros L, Guimarães J, Carrilho F, Carvalheiro M. Friedreich ataxia and diabetes mellitus-family study. Acta Med Port 2005;18(6):479-483

10 Baloh RW, Konrad HR, Honrubia V. Vestibulo-ocular function in patients with cerebellar atrophy. Neurology 1975;25(2):160-168

11 Zeigelboim BS, Jurkiewicz AL, Fukuda Y, Mangabeira-Albernaz PL. Alterações vestibulares em doenças degenerativas do sistema nervoso central. Pró-Fono 2001;13(2):263-270

12 Dueñas AM, Goold R, Giunti P. Molecular pathogenesis of spinocerebellar ataxias. Brain 2006;129(Pt 6):1357-1370

13 Schöls L, Bauer P, Schmidt T, Schulte T, Riess O. Autosomal dominant cerebellar ataxias: clinical features, genetics, and pathogenesis. Lancet Neurol 2004;3(5):291-304

14 Pearson CE, Nichol Edamura K, Cleary JD. Repeat instability: mechanisms of dynamic mutations. Nat Rev Genet 2005;6(10):729-742

15 Schmitz-Hübsch T, du Montcel ST, Baliko L, et al. Scale for the assessment and rating of ataxia: development of a new clinical scale. Neurology 2006;66(11):1717-1720

16 Braga-Neto P, Godeiro-Junior C, Dutra LA, Pedroso JL, Barsottini OGP. Translation and validation into Brazilian version of the scale of the assessment and rating of ataxia (SARA). Arq Neuropsiquiatr 2010;68(2):228-230

17 Mangabeira-Albernaz PL, Ganança MM, Pontes PAL. Modelo operacional do aparelho vestibular. In: Mangabeira-Albernaz PL, Ganança MM. Vertigem. 2ㄹ. ed. São Paulo: Moderna; 1976:29-36
18 Costa KCF, Silva SMR, Ganança CF. Estudo das provas oculomotoras e vestibulares por meio da vectonistagmografia. Distúrb Comum 2005;17:315-322

19 Teive HAG. Spinocerebellar ataxias. Arq Neuropsiquiatr 2009; 67(4):1133-1142

20 Zeigelboim BS, Ghizoni Teive HA, Sampaio R, et al. Otoneurological findings in spinocerebellar ataxia. Int Tinnitus J 2011;16(2):161-167

21 Klockgether T. Recent advances in degenerative ataxias. Curr Opin Neurol 2000;13(4):451-455

22 Ito YI, Mizrahi EI, Zeigelboim BS, Suzuki MR. Síndrome de Friedreich. Acta AWHO 1993;12(1):39-41

23 Nakamagoe K, Iwamoto Y, Yoshida K. Evidence for brainstem structures participating in oculomotor integration. Science 2000;288(5467):857-859

24 Cogan DG, Chu FC, Reingold DB. Ocular signs of cerebellar disease. Arch Ophthalmol 1982;100(5):755-760

25 Takegoshi H, Murofushi T. Vestibular evoked myogenic potentials in patients with spinocerebellar degeneration. Acta Otolaryngol 2000;120(7):821-824

26 Prim-Espada MP, de Diego-Sastre JI, Martínez-Salio A, de SarriáLucas MJ. [Electrooculography findings in Friedreich's ataxia]. Rev Neurol 2005;40(2):78-80

27 Fahey MC, Cremer PD, Aw ST, et al. Vestibular, saccadic and fixation abnormalities in genetically confirmed Friedreich ataxia. Brain 2008;131(Pt 4):1035-1045

28 Hocking DR, Fielding J, Corben LA, et al. Ocular motor fixation deficits in Friedreich ataxia. Cerebellum 2010;9(3):411-418

29 Noval S, Contreras I, Sanz-Gallego I, Manrique RK, Arpa J. Ophthalmic features of Friedreich ataxia. Eye (Lond) 2012;26(2):315-320

30 Monday LA, Lemieux B. [Audiovestibular study in Friedreich's ataxia]. J Otolaryngol 1978;7(5):415-423

31 Kirkham TH, Guitton D, Katsarkas A, Kline LB, Andermann E. Oculomotor abnormalities in Friedreich's ataxia. Can J Neurol Sci 1979;6(2):167-172 